\title{
Realizacja praw i wolności w obliczu współczesnych problemów gospodarczych i społecznych
}

Oddajemy w Państwa ręce trzydziesty piąty tom „Studenckich Prac Prawniczych, Administratywistycznych i Ekonomicznych" zatytułowany Realizacja praw $i$ wolności w obliczu współczesnych problemów gospodarczych i społecznych. Opracowanie zbiera wyniki badań młodych naukowców — studentów, doktorantów i doktorów, którzy podjęli się ich zaprezentowania w formie artykułów o tematyce prawno-ekonomicznej.

Problematyka praw i wolności kształtujących się w tyglu współczesnych problemów gospodarczych i społecznych jest niezmiennie ciekawa i wielowątkowa. Prawa podmiotowe stanowią złożoną konstrukcję pojęciową, a rolą prawodawcy i praktyki jest „odkrywanie” ich treści i takie kształtowanie prawa, aby zostały one objęte pełną ochroną ${ }^{1}$ Szczególnym przypadkiem uprawnień podmiotów prawa są wolności prawnie chronione, które pojawiają się wtedy, gdy prawo zakazuje podmiotom ingerencji w sferę działalności podmiotu korzystającego z tej wolności²

$\mathrm{W}$ tomie podjęto wiele tematów, które przedstawiają współczesne problemy gospodarcze i społeczne oraz zestawiono je z tym, jak poszczególne jednostki w ich ramach realizują swoje prawa i wolności. W tym ujęciu prawo będzie formą wyrazu, swego rodzaju odpowiedzią wobec ciągle zmieniającej się rzeczywistości.

Spośród tematów skupiających się na prawach podmiotowych określonych grup zaprezentowane zostały refleksje autorów dotyczące postulatów wprowadzenia domniemania istnienia stosunku pracy, dopuszczalności prawa do strajku personelu medycznego, a także uzyskiwania uprawnień emerytalnych przez byłych i obecnych funkcjonariuszy celnych. Opisana została również współpraca podmiotów działających w mediach społecznościowych z przedsiębiorcami.

Prawo publiczne, z prawem podatkowym na czele, coraz aktywniej wpływa na funkcjonowanie podmiotów życia społecznego, kształtując ich uprawnienia i obo-

1 Wprowadzenie do nauk prawnych. Leksykon tematyczny, red. A. Bator, Warszawa 2008, s. 303-304.

2 Ibidem, s. 311. 
wiązki względem poszczególnych skarbów publicznych. Tworzone są nowe instytucje, których celem jest rozwiązanie aktualnych bolączek prawa podatkowego. W tym tomie podjęto próby oceny dwóch takich rozwiązań: Wiążącej Informacji Stawkowej i mechanizmu split payment.

Współcześnie tworzone prawo, reagując na zachodzące przemiany społeczne, obejmuje coraz szersze kategorie podmiotów. W tym kontekście warto zapoznać się z artykułem obejmującym problematykę rozszerzania prawnej podmiotowości zwierząt.

Na łamach tomu znalazły się również opinie odnośnie do funkcjonowania prawa operatywnego. Czytelnicy mogą zapoznać się z uwagami na tle uchwały Sądu Najwyższego dotyczącymi kary umownej za brak lub nieterminową zapłatę wynagrodzenia podwykonawcom, a także odnoszącymi się do wyroku Trybunału Konstytucyjnego wydanego w związku z dotychczasową praktyką funkcjonowania Krajowego Ośrodka Zapobiegania Zachowaniom Dyssocjalnym. Przedstawione zostały także wymóg skutecznej ochrony sądowej jako element praworządności w prawie Unii Europejskiej oraz odpowiedź na pytanie: „komu potrzebny jest lobbing?”.

Aktualnie istotnym problemem dla światowych gospodarek jest ochrona środowiska. Ten temat poruszony został także w niniejszym tomie, w postaci rozważań dotyczących ochrony środowiska w przepisach rangi konstytucyjnej w państwach byłej Jugosławii, a także statusu prawnego prosumenta energii odnawialnej.

Niektórzy autorzy przedstawiają konkretne zjawisko gospodarczo-społeczne, co stanowi niejako zaproszenie do dalszej dyskusji nad tematem. W takim ujęciu w tomie zaprezentowano kwestię wydatków na ochronę zdrowia, dokonywanych zarówno przez Skarb Państwa, jak i przez gospodarstwa domowe.

Czytelnik w ramach tego opracowania będzie mógł dowiedzieć się także, jak realizowana jest swoboda przedsiębiorczości w przypadku notariuszy działających w Unii Europejskiej, zgłębić czym jest dual listing w kontekście integracji rynków kapitałowych, zrozumieć znaczenie prawa własności intelektualnej w przemyśle modowym, jak również rozważyć problemy definicyjne związane $\mathrm{z}$ pojęciem ubóstwa.

W związku z tym, że tematy historyczne są istotne dla współczesności, gdyż można w nich odnaleźć uniwersalne prawdy, w tomie znalazł się także artykuł opisujący najwcześniejsze prawo wydobycia złota na Śląsku.

Oddając w ręce czytelników kolejny tom „Studenckich Prac Prawniczych, Administratywistycznych i Ekonomicznych", wyrażamy nadzieję, że przyczyni się on do pełniejszego zrozumienia współczesnych problemów gospodarczych i społecznych, które trapią młodych naukowców, i stanie się przyczynkiem do dalszych badań w tych obszarach.

Dominik Kossak

ORCID: 0000-0002-0680-5104 Uniwersytet Wrocławski 